DOI: $10.28934 /$ jwee18.12.pp1-16

ORIGINAL SCIENTIFIC PAPER

\title{
How Does State and Local Government Support Affect Entrepreneurs' Gender, Age and Race?
}

\author{
Halil Dincer Kaya ${ }^{1}$ \\ Northeastern State University, College of Business and Technology, Department of \\ Accounting and Finance, Oklahoma, United States
}

\section{A B S T R A C T}

In this study, we test whether state and local government support attract female entrepreneurs. We also test to see whether government support attracts younger entrepreneurs and minorities. First, we differentiate between the U.S. states where state government support is high and the U.S. states where state government support is low. Then, we compare small business owners' gender, age, and race across high-and low-state government support states. We find that there is no significant difference in owners' gender across high- and low-state government support states. However, our results show that, in the states where state government support is high, there are more young entrepreneurs (age 25-34) and fewer middle-aged entrepreneurs (age 45-54) when compared to the other states. Our results also show that, in these states, there are fewer Asian or Hispanic entrepreneurs when compared to the other states. When we differentiate between the states where local government support is high and the states where local government support is low, we find that there is no significant difference in owners' gender or age across high-and low-local government support states. However, our results show that, in the states where the local government support is high, there are more white entrepreneurs and fewer Asian or Hispanic entrepreneurs.

1 Address: 3100 E. New Orleans St., Broken Arrow, Oklahoma, USA, e-mail: kaya@nsuok.edu 
KEY WORDS: government support, small firm, small business, entrepreneurship, entrepreneur, owner characteristics

\section{Introduction}

In this study, we examine whether high levels of government support for small businesses attract certain types of entrepreneurs into a state. First, we look into the impact of state government's support on entrepreneurs' gender, age, and race. Then, we examine the impact of local government's support on entrepreneurs' gender, age, and race.

There is a survey titled "United States Small Business Friendliness Survey" which asks small business owners questions on their state and local government's support. We use the responses in this survey in our analysis. We name the U.S. states with high scores on the state government support question as the "high-Stategovtsupport score states" and the U.S. states with low scores on the state government support question as the "lowStategovtsupport score states". Then, using nonparametric tests, we compare the two groups of states in terms of the entrepreneurs' gender, age, and race. After that, we do a similar analysis for local government support. We compare the states with high scores in local government support to the states with low scores in local government support.

By doing these analyses, this study will demonstrate the relation between government support and entrepreneur's gender, age, and race. If female entrepreneurs need and expect government's support to start a business, then we should find a positive relation between government support and the percentage of female entrepreneurs in a state. If younger entrepreneurs or minorities expect government's support to start a business, then we should find a positive relation between government support and the percentage of younger entrepreneurs or minority entrepreneurs in a state.

We believe that the findings here on gender, age, and race will guide state and local government officials when forming their policies. If a state or a city/town wants to attract certain types of entrepreneurs, they can increase their support for small businesses. Conversely, if a state or a city/town wants to avoid attracting such entrepreneurs into their area, they can reduce their support for small businesses.

The paper continues as follows: Section 2 goes over the previous literature. Section 3 explains the data used in this study. Section 4 presents the empirical results. Section 5 concludes. 


\section{Literature Review}

Several papers look into the relation between government support and entrepreneurship. Ariff and Abubakar (2002) argue that past and current policies to create a class of entrepreneurs in Malaysia have succeeded. However, the authors argue that, the transformation from a manufacturingbased to a knowledge-based economy brings in changes in these companies' needs and demands; therefore, a closer relation between the entrepreneurs and the government is needed. According to Ariff and Abubakar (2002), bureaucratic delays and red tape are major blocks to entrepreneurs. Still, the authors believe that the government recognizes the importance of its tasks including ensuring a healthy political and economic climate, encouraging corporate governance, making funds available to stop the liquidity crunch, designing guidelines and regulations to ensure intellectual property right protections, and providing the entrepreneurs with more guidance and training.

Bennett (2008) examines the evolution of British government support to small and medium-sized enterprises (SMEs). The author uses four surveys done, and also uses comparisons with other analyses. According to the author, government support is often based on overcoming market failures in the availability or use of supports to SMEs. However, Bennett (2008) argues that successful government intervention is difficult to make effective at realistic cost - benefit ratios. The author also shows that female entrepreneurs do not use government support as much as male entrepreneurs. The author concludes that, over the 1991-2004 period, there is not much evidence that indicates the overwhelming success of government SME support policies, especially when the cost levels are considered.

Carland and Carland (2004) argue that small firms are very important for societies, therefore economic development policies should specifically target these firms. According to the authors, if the U.S. economic development efforts targeted this smallest firm sector, and if they only had an average of a $10 \%$ improvement in performance, the nation would have experienced a $42 \%$ increase in employment growth.

According to Carlsson and Mudambi (2003), after activity starts and clusters form, a comprehensive set of facilitating policies (including information provision and networking, tax codes and labor laws) are necessary. According to Carlsson and Mudambi (2003), these policies must 
consider both cluster development and the life cycles of individual small firms. The authors also contend that government policy should focus on making entrepreneurship easy. Higher opportunity cost of entrepreneurship lowers the quality of entrepreneurs, since in that case, "the only agents willing to undertake entrepreneurship are those who cannot do anything else".

Fatoki and Chindoga (2011) find that youths in South Africa perceive lack of skill, lack of capital, lack of market opportunities, lack of support, and risk as the main obstacles to entrepreneurial intention. The authors recommend governments to reduce the obstacles to youth entrepreneurship.

Fischer and Reuber (2003) find that policymakers and external resources providers have incentives to interact with rapid growth firms, but, although rapid growth firms also have an incentive to interact with these other two groups, they prefer to obtain advice from their peers. The authors recommend a network-based approach for supporting the rapid growth firms.

Gilbert et al. (2004) argue that public policy towards business is undergoing a profound shift. According to the authors, governments around the world have designed a new set of policies to promote entrepreneurial activity and these policies focus on enabling the startup and increasing the viability of entrepreneurial firms rather than constraining existing enterprises.

Henrekson and Rosenberg (2001) examine science-based entrepreneurship in the US. and Sweden. They show that despite comprehensive government support and high R\&D spending in Sweden, science-based entrepreneurship has been far less important compared to the U.S. The authors point to weaknesses in several areas in Sweden. These are "the rate of return to human capital investment, incentives to become an entrepreneur and to expand existing businesses, and insufficient incentives within the university system to adjust curricula and research budgets to outside demand". The authors suggest that policies "should focus on strengthening individual incentives for human capital investment and entrepreneurial behavior both within universities and in business".

Keuschnigg and Nielsen (2001) analyze several policy measures addressed at venture capital activity: subsidies to equipment investment, government spending on entrepreneurial training, and output subsidies at the production stage. The authors contend that while these measures stimulate 
entrepreneurship, only cost-effective government services can improve welfare.

Korosec and Berman (2006) examine how cities help social entrepreneurship. They find that municipalities help social entrepreneurs in several ways. These include helping entrepreneurs to acquire resources, to coordinate with other organizations, and to implement programs. Municipalities also help by increasing awareness of social problems in the community. The authors explain that nearly three-quarters of cities provide active or moderate support.

Fredric and Zolin (2005) examine the role that government technology programs can play in facilitating the process of technological entrepreneurship. They explore relationships between these programs and environmental factors, entrepreneurial orientation, firm performance, and organizational factors. According to the authors, "technology development programs should take the capabilities and interests of the small firms into account when deciding whether their top priority is technology development or commercialization".

Lee et al. (2006) examine entrepreneurship education in the US, Korea, China and Fiji. They show that, in order to have an effective entrepreneurship education, each country needs a customized approach based on its cultural context.

Li (2002) examines the effects of government credit subsidies on entrepreneurial activity. The author finds that "credit assistance programs in the form of interest subsidies exert strong effects on the allocation of credit to targeted entrepreneurs, but at the cost of non-targeted entrepreneurs". According to the author, as a result, total entrepreneurial activities and output go down. The author also examines several alternative credit programs. Li (2002) finds that "income subsidy programs and programs that specifically target poor and capable entrepreneurs are more effective in promoting entrepreneurial activity and improving total output".

Markman et al. (2004) examine the relation between monetary incentives to inventors, their department or institution, or to university technology transfer office increase entrepreneurial activities at U.S. universities. They find that incentives to scientists and to their departments are negatively related to entrepreneurial activity. On the other hand, incentives to university technology transfer office is positively related to entrepreneurial activity. 
McQuaid (2002) argues that the term "entrepreneurship" has been used inconsistently in research. According to the author, the previous papers focus on one of the following five different definitions of entrepreneurship: "a particular function in the economy (such as innovation, risk-taking or allocation of resources); a new business startup; an owner-manager or SME; a set of personal or socio-psychological characteristics; and, a form of behavior". The author presents a three-stage model that covers different stages of the entrepreneurial process that are linked to different perspectives of entrepreneurship.

Michael and Pearce (2009) argue that some governments support entrepreneurship as a means to create jobs while others support entrepreneurship as a means to create competition in markets. The authors examine government support that focuses on supporting and encouraging innovation. The authors also show that aiding entrepreneurship without a commitment to innovation is unlikely to be as successful as the support that focuses on innovation.

Rasmussen (2008) examines Canadian government's support for the commercialization of publicly funded research. The authors differentiate between two types of programs: Programs providing support to specific commercialization projects and programs made to induce structural reforms within the university sector. According to the author, Canadian government provides resources for direct use in commercialization projects, supports the development of professional expertise in technology transfer, supports experimentation with new initiatives, and facilitates cooperation between commercializing organizations.

Rasmussen and Borch (2010) propose three university capabilities that facilitate the venture-formation process within the university sector: Creating new paths of action, balancing both academic and commercial interests, and integrating new resources. According to the authors, each of these capabilities is particularly important for specific phases in the venturing process.

Rothwell and Zegveld (1982) explain that SMEs (i.e. small and medium sized enterprises) serve as a significant source of employment. They lead to a more favorable balance of economic power and also they mutually benefit small/large firm relations. Additionally, in certain industry sectors, small firms contribute to a disproportionately high percentage of radical innovations. Therefore, SMEs should receive more government support. The authors conclude that "SMEs are essential to the innovative 
progress of the economy, especially playing highly significant roles at the early, fluid stages of development in new technological industries".

Sebora et al. (2009) examine the critical success factors for ecommerce entrepreneurship in Thailand. They find that while achievement orientation and emphasis on reliability and ease of use all have a positive impact on these firms' success, government support has an insignificant impact.

Todd and Javalgi (2007) examine how information technology and communication infrastructure affects SMEs in India. According to the authors, to achieve international growth, SMEs need better infrastructure. The authors imply that, in order to promote international growth by SMEs, governments should focus on improving the infrastructure.

Trajtenberg (2002) examines the role of government support for commercial R\&D in Israel. According to the author, it is highly likely that government policies significantly contributed to the high-tech sector's success. The author contends that "the key to the apparent success of R\&D policies seems to have been both boldness in the deployment of resources, and flexibility and creativity (i.e. innovativeness) in responding to rapidly changing needs and challenges".

Wiklund and Shepherd (2008) differentiate between novice and habitual (i.e. portfolio) entrepreneurs. They show that "whether or not business founders subsequently pursue portfolio entrepreneurship is explained by their human capital (education and start-up experience) and social capital (business networks and links with government support agencies).

\section{Data and Methodology}

We employ a national survey done by Kauffman Foundation and Thumptack.com in 2013. It is called "United States Small Business Friendliness Survey". This survey asks small business owners their opinions on their state government's and local government's support for small businesses. The respondents answer the following two questions:

\footnotetext{
"In general, how would you rate your state government's support of small business owners?”

"In general, how would you rate your local (county, city, or town) government's support of small business owners?”
} 
For both questions, the respondents chose one of the following five answers:

"Very supportive" (we coded as "4"), "Somewhat supportive" (we coded as "3"), "Neither supportive nor unsupportive" (we coded as "2"), "Somewhat unsupportive" (we coded as "1"), and "Very unsupportive" (we coded as "0").

Then, we compute the average score for each question for each state. There are 41 states with enough data, so using the averages for each state, we assign a "Stategovtsupportscore" and a "Localgovtsupportscore" for each state. Therefore, our first two variables are the "Stategovtsupportscore" and "Localgovtsupportscore" variables.

The survey also asks questions on the owner's gender, age, and race. For each state, we compute the percentage of female owners, and this is our third variable. We call this variable "Female".

Using the survey answers, we also compute the percentage of owners in each state that are in certain age groups. These age groups are Age $<25$, Age25-34, Age35-44, Age45-54, Age55-64, and Age >64. These are our "age" variables.

Again, using the survey questions, we compute the percentage of owners in each state that belong to certain races. These race groups are Asian, Black, Hispanic, White, and Otherrace. These are our "race" variables.

Table 1 shows the summary statistics for our variables.

Table 1: Summary Statistics (All Variables in \%)

\begin{tabular}{lrrrrr}
\hline Variable & Mean & Median & Stdev & Min & Max \\
\hline Stategovtsupportscore & 2.42 & 2.43 & 0.23 & 1.96 & 2.92 \\
Localgovtsupportscore & 2.54 & 2.57 & 0.20 & 2.00 & 2.97 \\
Female & 37.00 & 36.96 & 5.96 & 21.05 & 52.94 \\
Age $<25$ & 2.09 & 2.18 & 1.67 & 0.00 & 8.70 \\
Age25-34 & 18.72 & 19.21 & 5.14 & 5.26 & 35.48 \\
Age35-44 & 24.27 & 25.32 & 3.98 & 14.29 & 31.82 \\
Age45-54 & 28.18 & 28.46 & 5.88 & 10.00 & 46.67 \\
Age55-64 & 21.38 & 20.45 & 6.32 & 8.70 & 42.11 \\
Age $>64$ & 5.36 & 5.71 & 2.61 & 0.00 & 11.43 \\
Asian & 1.67 & 1.12 & 2.73 & 0.00 & 16.67
\end{tabular}




\begin{tabular}{lrrrrr}
\hline Variable & Mean & Median & Stdev & Min & Max \\
\hline Otherrace & 5.38 & 4.21 & 5.34 & 0.00 & 26.67 \\
Black & 7.36 & 4.84 & 7.72 & 0.00 & 34.71 \\
Hispanic & 4.95 & 3.85 & 4.26 & 0.00 & 16.16 \\
White & 80.63 & 81.82 & 11.33 & 53.33 & 100.00 \\
\hline
\end{tabular}

As the table shows, the mean "Stategovtsupportscore" for the 41 states is 2.42. As explained above, we coded "Somewhat supportive" as "3", and "Neither supportive nor unsupportive" as "2". Therefore, a mean score of 2.42 indicates that, in the average U.S. state, the small business owners believe that there is just not much support available to them by their state government.

The mean "Localgovtsupportscore" for the 41 states is 2.54. Again, this means that, in the average U.S. state, the small business owners believe that there is just not much support available to them by their local government.

The mean value of "Female" is 37.00 , meaning that, in the average U.S. state, $37 \%$ of the small business owners are female.

When we look at the age groups, we are seeing that, in the average state, only $2.09 \%$ of the owners are younger than 25 years of age. $18.72 \%$ are 25 to 34 years of age, $24.27 \%$ are 35 to 44 years of age, $28.18 \%$ are 45 to 54 years of age, $21.38 \%$ are 55 to 64 years of age, and only $5.36 \%$ are older than 64 years of age.

When we look at the race groups, we are seeing that, in the average state, only $1.67 \%$ of the owners are "Asian", $5.38 \%$ are from other races, $7.36 \%$ are "Black", and $4.95 \%$ are "Hispanic". We are seeing that $80.63 \%$ are "White".

In order to do the analyses, we run nonparametric tests (i.e. Mann Whitney Wilcoxon tests) that compare states with high and low scores in terms of "Stategovtsupportscore". We also compare states with high and low scores in terms of "Localgovtsupportscore". In order to differentiate between high and low score states in each category (i.e. "Stategovtsupportscore" and "Localgovtsupportscore"), we use the mean values. The states with scores higher than the mean are classified as highscore states, and the states with scores lower than the mean are classified as low-score states.

In the next section, we first show the results of our comparisons between high-Stategovtsupportscore states and low-Stategovtshupportscore 
states. Then, we show the results of our comparisons between highLocalgovtsupportscore states and low-Localgovtshupportscore states.

\section{Empirical Results}

Table 2 shows the results of our comparisons between the high-state government support states and the low-state government support states. Panel A examines the differences between the two groups of states in terms of the gender of small business owners. Panel B examines the differences between the two groups of states in terms of the age of small business owners. Panel $\mathrm{C}$ looks into the differences between the two groups of states in terms of the race of small business owners.

Table 2: Gender, Age and Race (Stategovtsupport)

\begin{tabular}{lrrrrr}
\hline \multicolumn{1}{c}{ Variable } & \multicolumn{2}{c}{ High-Score } & \multicolumn{2}{c}{ Low-Score } & Mann-W. \\
& Mean & Med. & Mean & Med. & p-value \\
\hline Panel A. Gender & & & & & \\
Female & 37.60 & 37.15 & 36.31 & 36.94 & 0.3190 \\
Panel B. Age & & & & & \\
Age<25 & 1.93 & 2.15 & 2.29 & 2.27 & 0.3862 \\
Age25-34 & 19.62 & 19.63 & 17.68 & 16.94 & $* 0.0771$ \\
Age35-44 & 24.56 & 25.62 & 23.92 & 24.68 & 0.2281 \\
Age45-54 & 26.90 & 26.79 & 29.67 & 29.03 & $* 0.0584$ \\
Age55-64 & 20.83 & 19.83 & 22.01 & 20.55 & 0.2960 \\
Age>64 & 6.15 & 5.58 & 4.43 & 5.80 & 0.1448 \\
Panel C. Race & & & & & \\
Asian & 1.02 & 1.10 & 2.44 & 1.61 & $* 0.0847$ \\
Otherrace & 4.99 & 4.08 & 5.84 & 4.35 & 0.3187 \\
Black & 8.24 & 4.63 & 6.35 & 4.84 & 0.3917 \\
Hispanic & 4.00 & 2.92 & 6.06 & 5.24 & $* * 0.0457$ \\
White & 81.75 & 82.63 & 79.33 & 81.45 & 0.2609 \\
\hline
\end{tabular}

Panel A shows that there is no significant difference in small business owners' gender across high- and low-state government support states. When we look at the median values, while $37.15 \%$ of the owners are female in the high-state government support states, the corresponding percentage is 
$36.94 \%$ in the low-state government support states. The difference is statistically insignificant $(\mathrm{p}=0.3190)$.

Panel B shows that, in the states where state government support is high, there are more young entrepreneurs (age25-34) and fewer middle-aged entrepreneurs (age45-54), when compared to the other states. While 19.63\% of the owners are of age 25 through 34 in the high-state government support states, the corresponding percentage in the low-state government support states is only $16.94 \%$. The difference between the two groups of states is statistically significant $(\mathrm{p}=0.0771)$. On the other hand, while only $26.79 \%$ of the owners are of age 45 through 54 in the high-state government support states, the corresponding percentage in the low-state government support states is $29.03 \%$. Here, the difference between the two groups of states is also statistically significant $(\mathrm{p}=0.0584)$. We do not find any significant difference between the two groups of states with respect to the other age groups.

Panel $\mathrm{C}$ shows that, in the states where state government support is high, there are fewer Asian or Hispanic entrepreneurs when compared to the other states. These results imply that Asian and Hispanic entrepreneurs, on average, do not adequately take advantage of state governments' support. While only $1.10 \%$ of the owners are Asian in the high-state government support states, the corresponding percentage in the low-state government support states is $1.61 \%$. The difference between the two groups of states is statistically significant $(\mathrm{p}=0.0847)$. On the other hand, while only $2.92 \%$ of the owners are Hispanic in the high-state government support states, the corresponding percentage in the low-state government support states is $5.24 \%$. Here, the difference between the two groups of states is also statistically significant $(\mathrm{p}=0.0457)$. With respect to the other race groups (i.e. White, Black, or Other Race), we do not find any significant difference between the two groups of states.

Table 3 shows the results of our comparisons between the high-local government support states and the low-local government support states. Panel A examines the differences between the two groups of states in terms of the gender of small business owners. Panel B examines the differences between the two groups of states in terms of the age of small business owners. Panel $\mathrm{C}$ looks into the differences between the two groups of states in terms of the race of small business owners. 
Table 3: Gender, Age and Race (Localgovtsupport)

\begin{tabular}{lrrrrr}
\hline \multicolumn{1}{c}{ Variable } & \multicolumn{2}{c}{ High-Score } & \multicolumn{2}{c}{ Low-Score } & Mann-W. \\
& Mean & Med. & Mean & \multicolumn{1}{c}{ Med. } & p-value \\
\hline Panel A. Gender & & & & & \\
Female & 37.64 & 37.15 & 36.27 & 36.94 & 0.2483 \\
Panel B. Age & & & & & \\
Age<25 & 1.89 & 2.17 & 2.33 & 2.27 & 0.3134 \\
Age25-34 & 18.81 & 19.47 & 18.63 & 18.64 & 0.3097 \\
Age35-44 & 24.77 & 25.62 & 23.68 & 24.68 & 0.2202 \\
Age45-54 & 27.22 & 26.79 & 29.29 & 28.57 & 0.1361 \\
Age55-64 & 21.54 & 20.23 & 21.19 & 20.55 & 0.4121 \\
Age>64 & 5.77 & 5.30 & 4.87 & 5.88 & 0.2781 \\
Panel C. Race & & & & & \\
Asian & 0.99 & 0.77 & 2.46 & 1.61 & $* 0.0711$ \\
Otherrace & 4.62 & 3.73 & 6.26 & 4.52 & $* 0.0596$ \\
Black & 6.61 & 3.95 & 8.24 & 5.05 & 0.2085 \\
Hispanic & 3.63 & 2.82 & 6.48 & 5.53 & $* * * 0.0044$ \\
White & 84.15 & 86.28 & 76.56 & 79.01 & $* * 0.0242$ \\
\hline
\end{tabular}

Panel A shows that there is no significant difference in small business owners' gender across high- and low-local government support states. When we look at the median values, while $37.15 \%$ of the owners are female in the high-local government support states, the corresponding percentage is $36.94 \%$ in the low-local government support states. The difference is statistically insignificant $(\mathrm{p}=0.2483)$.

Panel B shows that there is no significant difference between the two groups of states in terms of the percentages of any age groups. Combining Panel A and Panel B results, we can say that there is no statistically significant relation between the level of local government support and owners' gender or age.

Panel C shows that, in the states where local government support is high, there are more white entrepreneurs and fewer Asian or Hispanic entrepreneurs. There are also fewer entrepreneurs from other races. While $86.28 \%$ of the owners are White in the high-local government support states, the corresponding percentage in the low-local government support 
states is only $79.01 \%$. The difference between the two groups of states is statistically significant $(\mathrm{p}=0.0242)$. On the other hand, while only $0.77 \%$ of the owners are Asian in the high-local government support states, the corresponding percentage in the low-local government support states is $1.61 \%$. Here, the difference between the two groups of states is also statistically significant $(\mathrm{p}=0.0711)$. Also, while only $3.73 \%$ of the owners are from other races in the high-local government support states, the corresponding percentage in the low-local government support states is $4.52 \%$. Here, the difference between the two groups of states is also statistically significant $(\mathrm{p}=0.0596)$. Finally, while only $2.82 \%$ of the owners are Hispanic in the high-local government support states, the corresponding percentage in the low-local government support states is $5.53 \%$. The difference between the two groups of states is statistically significant $(p=0.0044)$. With respect to the percentage of Black entrepreneurs, we do not find any significant difference between the two groups of states.

\section{Conclusion}

In this study, we examine the impact of government support on small business owners' gender, age, and race. For this purpose, we employ the "United States Small Business Friendliness Survey" which was done by Kauffman Foundation and Thumptack.com in 2013. This survey asks small business owners questions about their feelings regarding their state and local governments' support for small businesses. The survey also has questions on owners' gender, age, and race.

In order to do our empirical analysis, first, we differentiate between the U.S. states where state government support is high and the U.S. states where state government support is low. Then, we compare small business owners' gender, age, and race across high- and low-state government support states. Our results show that there is no significant difference in owners' gender across high- and low-state government support states.

When we look into the relation between state government support and owners' age, however, we find that, in the states where state government support is high, there are more young entrepreneurs (age25-34) and fewer middle-aged entrepreneurs (age45-54) when compared to the other states. We do not find any significant difference between the two groups of states with respect to the other age groups. 
When we look into the relation between state government support and owners' race, we find that in the states where state government support is high, there are fewer Asian or Hispanic entrepreneurs when compared to the other states. These results imply that Asian and Hispanic entrepreneurs, on average, do not adequately take advantage of state governments' support. With respect to the other race groups (i.e. White, Black, or Other Race), we do not find any significant difference between the two groups of states.

Then, we continue with our analysis by differentiating between the states where local government support is high and the states where local government support is low. When we compare the two groups of states, we find no significant difference in small business owners' gender or age. In other words, there is no relation between the level of local government support and owners' gender or age.

When we look into the relation between local government support and owners' race, we find that in the states where local government support is high, there are more white entrepreneurs and fewer Asian or Hispanic entrepreneurs. There are also fewer entrepreneurs from Other races.

In this study, we document whether high levels of state or local government support within a state attract certain types of entrepreneurs into that state. Although we do not find any evidence of female entrepreneurs being attracted into a state that offers high levels of support, we show that certain age groups or certain races can be attracted through government support.

We believe that the findings here will guide state and local government officials when forming their policies. If a state or a city/town wants to attract certain types of entrepreneurs, they can utilize the results here. This would allow them to be more effective when using their resources.

\section{References}

[1] Ariff, Mohamed, and Syarisa Yanti Abubakar. 2002. "Strengthening entrepreneurship in Malaysia." Malaysian Economic Outlook: 1st Quarter 2002 Update, 1-22.

[2] Bennett, Robert. 2008. "SME policy support in Britain since the 1990s: what have we learnt?" Environment and Planning C: Government and Policy, 26(2): 375-397.

[3] Carland, JoAnn C., and James W. Carland. 2004. "Economic development: Changing the policy to support entrepreneurship." Academy of Entrepreneurship Journal, 10(1-2): 105. 
[4] Carlsson, Bo, and Ram Mudambi. 2003. "Globalization, entrepreneurship, and public policy: a systems view." Industry and Innovation, 10(1): 103-116.

[5] Fatoki, Olawale Olufunso, and Lynety Chindoga. 2011. "An investigation into the obstacles to youth entrepreneurship in South Africa." International Business Research, 4(2), 161.

[6] Fischer, Eileen, and A. Rebecca Reuber. 2003. "Support for rapid-growth firms: a comparison of the views of founders, government policymakers, and private sector resource providers." Journal of small business management, 41(4): 346-365.

[7] Gilbert, Brett Anitra, David B. Audretsch, and Patricia P. McDougall. 2004. "The emergence of entrepreneurship policy." Small Business Economics, 22(3): 313-323.

[8] Henrekson, Magnus, and Nathan Rosenberg. 2001. "Designing efficient institutions for science-based entrepreneurship: Lesson from the US and Sweden." The journal of technology transfer, 26(3): 207-231.

[9] Keuschnigg, Christian, and Soren Bo Nielsen. 2001. "Public policy for venture capital." International Tax and Public Finance, 8(4), 557-572.

[10] Korosec, Ronnie L., and Evan M. Berman. 2006. "Municipal support for social entrepreneurship." Public administration review, 66(3): 448-462.

[11] Fredric, Kropp, and Roxanne Zolin. 2005. "Technological entrepreneurship and small business innovation research programs." Academy of Marketing Science Review, 2005, 1.

[12] Lee, Sang M., Seong-bae Lim, Raghuvar D. Pathak, Daesung Chang, and Weixing Li. 2006. "Influences on students' attitudes toward entrepreneurship: a multi-country study." The International Entrepreneurship and Management Journal, 2(3): 351-366.

[13] Li, Wenli. 2002. "Entrepreneurship and government subsidies: A general equilibrium analysis." Journal of Economic Dynamics and control, 26(11): 1815-1844.

[14] Markman, Gideon D., Peter T. Gianiodis, Phillip H. Phan, and David B. Balkin. 2004. "Entrepreneurship from the ivory tower: Do incentive systems matter?." The Journal of Technology Transfer, 29(3): 353-364.

[15] McQuaid, Ronald W. 2002. "Entrepreneurship and ICT industries: support from regional and local policies." Regional Studies, 36(8), 909-919.

[16] Michael, Steven C., and John A. Pearce. 2009. "The need for innovation as a rationale for government involvement in entrepreneurship." Entrepreneurship and Regional Development, 21(3): 285-302.

[17] Rasmussen, Einar. 2008. "Government instruments to support the commercialization of university research: Lessons from Canada." Technovation, 28(8): 506-517. 
[18] Rasmussen, Einar, and Odd Jarl Borch. 2010. "University capabilities in facilitating entrepreneurship: A longitudinal study of spin-off ventures at mid-range universities." Research Policy, 39(5): 602-612.

[19] Rothwell, Roy, and Walter Zegveld. 1982. "Innovation and the small and medium sized firm." University of Illinois at Urbana-Champaign's Academy for Entrepreneurial Leadership Historical Research Reference in Entrepreneurship.

[20] Sebora, Terrence C., Sang M. Lee, and Nittana Sukasame. 2009. "Critical success factors for e-commerce entrepreneurship: an empirical study of Thailand." Small Business Economics, 32(3): 303-316.

[21] Todd, Patricia R., and Rajshekhar G. Javalgi. 2007. "Internationalization of SMEs in India: Fostering entrepreneurship by leveraging information technology." International journal of emerging markets, 2(2): 166-180.

[22] Trajtenberg, Manuel. 2002. "Government support for commercial R\&D: Lessons from the Israeli experience." Innovation policy and the economy, 2, $79-134$.

[23] Wiklund, Johan, and Dean A. Shepherd. 2008. "Portfolio entrepreneurship: Habitual and novice founders, new entry, and mode of organizing." Entrepreneurship Theory and Practice, 32(4): 701-725.

Article history: Received: 23 January, 2018

Accepted: 18 June, 2018 